\title{
Assessment of Beans as Functional Food for Control of Oxidative Stress Borne Diseases
}

\author{
Savita Chaurasia* and Saloni Gupta \\ Department of Biotechnology, IMS Engineering College, Ghaziabad, Dr. APJ Abdul Kalam Technical University, India
}

Submission: March 29, 2017; Published: May 30, 2017

"Corresponding author: Dr. Savita Chaurasia, Department of Biotechnology, IMS Engineering College, NH-24, Adyatmik Nagar, Ghaziabad 201009, UP, India, Tel: +911207945555; Email: drsav16@gmail.com

\begin{abstract}
Increased oxidative stress has been postulated in the diabetic state. Oxygen free radical activity can initiate peroxidation of lipids, which in turn stimulates glycation of protein, inactivation of enzymes and alterations in the structure and function of collagen, basement and other membranes and play a role in the long team complications of diabetes. Oxidative stress in diabetes coexists with a reduction in the antioxidant status, which can increase the deleterious effects of free radicals. It has also been known that alloxan induces its diabetogenic activity mainly by inducing oxygen free radicals and thereby damaging the pancreas. Supplementation with non-toxic antioxidants may have a chemoprotective role in the diabetes.

The study was undertaken to evaluate antioxidant potential of beans namely moth bean (Vigna aconitifolia), mung bean (Vigna radiata) and soybean (Glycine max). Water and methanol extracts were examined for antioxidant activity by DPPH radical scavenging assay, total phenol and flavanoid content were determined in both cases which showed maximum percentage of antioxidant activity in water extract of moth beans followed by soy and mung due to the presence of water soluble phenols and radicals more than that in methanol. The extracts also possess mild antibacterial property. Several physiological and biochemical parameters such as moisture content, seedling vigor, germination percent, total sugar and reduced sugar content during different period of germination showed gradual increment. Therefore, utilization of these legumes in the development of functional foods with increased therapeutic value would be a significant step toward health promotion and wellness.
\end{abstract}

Keywords: Legumes; Oxidative stress; Antioxidant potential; DPPH radical scavenging; Phenol; Flavanoid; Free radicals

\section{Introduction}

Nature has bestowed on us a very rich botanical wealth and a large number of diverse types of plants grow in different parts of the country. In India many of the plant species are known to have medicinal value. Herbal plants continue to be a major source of drugs and natural products on the basis of their therapeutics [1] in virtually all cultures [2]. The plants possess potent bioactive compounds capable of preventing and treating most oxidative related diseases [3] and have often been used in folkloric medicine [4]. In developing countries, the use of medicinal plants in the treatment of infectious disease is rife and reasons include the high cost of effective drugs [5]. However, potential indigenous plants exploited for medicinal purposes have to undergo basic phytochemical screening and bioassay as first step towards the ultimate development of drugs.

In search of natural antioxidants, we have studied the antioxidant activity, total phenols, flavonoids, metal chelating and radical scavenging properties of different varieties of Fabaceae (beans) in fresh condition. After getting positive results, study was extended with methanolic extracts. Findings of the study may be beneficial for mankind, as beans forms the major dietary component and can be treated as food supplement to overcome the oxidative stress due to present lifestyle, pollution, radiations, smoking, and certain pesticides etc. Academic, government and private research institutes around the globe are devoting substantial efforts to identify how functional foods and food ingredients might help prevent chronic disease or optimize health, thereby reducing healthcare costs and improving the quality of life for many consumers. The acceptance of biotechnology by consumers will be important if the potential of this powerful methodology is to be realized. Therefore, the present study aims at investigating the potentials of beans as a functional food for nutritional and therapeutic control of oxidative stress borne diseases.

\section{Material and Methods}

\section{Plant material}

The mung beans (Vigna radiata), moth beans (Vigna aconitifolia) and soy beans (Glycine max) were procured from local market of Ghaziabad, India.

\section{Chemicals}

Gallic acid and aluminium chloride hexahydrate were procured from Titan Biotech Ltd., Bhiwadi, India; folin- 
ciocalteu's phenol reagent was obtained from Sisco Research laboratories, Pvt. Ltd., Mumbai, India; Quercitin dihydrate and DPPH (1,1-diphenyl-2-picrylhydrazyl) were purchased from HIMEDIA laboratories Pvt. Ltd., Mumbai, India; Potassium thiocyanate and 2,2'- bipyridyl, potassium ferricyanide were obtained from Central Drug House Pvt. Ltd., New Delhi, India.

Other chemicals like ethanol, sodium carbonate, ascorbic acid, phosphate buffer, trichloroacetic acid, hydrogen peroxide, ferric chloride, ferrous sulphate, potassium acetate, EDTA used in the study were of analytical grade.

\section{Preparation of extracts}

$50 \mathrm{~g}$ of dried powder was taken in $500 \mathrm{ml}$ of solvent (water or methanol) in a conical flask, plugged with cotton wool and kept on a rotatory shaker at $190-200 \mathrm{rpm}$ for $24 \mathrm{~h}$. After that the extracts were centrifuged at $5000 \mathrm{~g}$ for $10 \mathrm{~min}$. The extract was filtered and was re-extracted by the same process until plant materials were exhausted. From the collected supernatant, solvents were evaporated and the dry extracts were stored at 4 ${ }^{\circ} \mathrm{C}$ in air tight bottle [6].

\section{Antioxidant Screening: DPPH radical scavenging assay}

The method of Mensor et al. [7] with slight modification was used. $1 \mathrm{ml}$ of $0.3 \mathrm{mM}$ DPPH in methanol was added to $2 \mathrm{ml}$ of each sample solutions (different concentration of extracts in methanol as per protocol) and allowed to react at room temperature in the dark for 30 minutes. The blank was prepared with $2 \mathrm{ml}$ sample solution and $1 \mathrm{ml}$ methanol while the negative control was $1 \mathrm{ml}$ DPPH solution and $2 \mathrm{ml}$ methanol. The decrease in absorbance was measured at $517 \mathrm{~nm}$.

These were converted to \% AA (antioxidant activity) using the formula:

$$
/ 1 / \% \mathrm{AA}=100-\{[(\mathrm{As}-\mathrm{Ab}) * 100] / \mathrm{Ac}\}
$$

Where, as was the absorbance sample, Ab was the absorbance of the blank and Ac was the absorbance of the control.

\section{Antioxidant Potential}

\section{Determination of total phenolic content}

Total phenolic contents were determined by the FolinCiocalteau method [8]. In brief, $0.1 \mathrm{ml}$ of each extract was mixed with $4.9 \mathrm{ml}$ distilled water, $0.5 \mathrm{ml}$ of Folin Ciocalteu reagent was added to the mixture. After incubation of $5 \mathrm{~min}, 5 \mathrm{ml}$ of $7 \%$ of aqueous $\mathrm{Na}_{2} \mathrm{CO}_{3}$ solution was added. The mixture was allowed to stand for 30 minutes and the absorbance was measured at $760 \mathrm{~nm}$ using a UV-Vis spectrophotometer (Systronics, model no. 2202). The standard curve was prepared by gallic acid $(0.1 \mathrm{mg} /$ $\mathrm{ml})$ in methanol: water $(50: 50, \mathrm{v} / \mathrm{v})$. Total phenolic content was expressed as of gallic acid equivalent $\mu \mathrm{g} \mathrm{GAE} / \mathrm{g}$ fresh weight.

\section{Determination of flavonoid content}

Aluminium chloride method was used for flavonoid content determination [8]. Briefly, $0.1 \mathrm{~mL}$ of each extract was mixed with $1.9 \mathrm{ml}$ distilled water, then $0.1 \mathrm{ml} 10 \%$ alluminium chloride hexa hydrate, $0.1 \mathrm{ml} 1 \mathrm{M}$ potassium acetate and $2.8 \mathrm{ml}$ of distilled water were added. The reaction mixture was incubated at room temperature for 40 minutes. The absorbance of the reaction mixture was measured at $415 \mathrm{~nm}$. Quercitin $(0.2 \mathrm{mg} / \mathrm{ml})$ was used as a standard. Total flavonoid content was expressed as $\mu \mathrm{g}$ QE/g fresh weight.

\section{Screening of Metal Chelating Activity}

\section{$\mathrm{Fe}^{2+}$ chelation}

The concentration of ferrous ion was estimated by $2,2^{\prime}$ bipyridyl- $\mathrm{Fe}^{2+}$ complex. The reaction mixture contained $0.01 \mathrm{~g}$ of $\mathrm{FeSO}_{4}, 1 \mathrm{ml}$ of $1 \mathrm{mM} \mathrm{NaCl}(\mathrm{pH} 7.0)$. Reaction mixture was incubated for $30 \mathrm{~min}$ at room temperature. At the end of incubation time, $2 \mathrm{ml}$ of $2,2^{\prime}$-bipyridal was added and absorbance of 2,2'-bipyridal- $\mathrm{Fe}^{2+}$ complex was measured at $525 \mathrm{~nm}$ in final volume of $3 \mathrm{ml}$ [9].

\section{$\mathrm{Fe}^{3+}$ chelation}

Iron (III) reacts with thiocyanate and gives an intensely red colour compound which remains in true solution. In the spectrometric determination a large excess of thiocynate should be used, since this increases the intensity and also the stability of the colour [9]. $0.01 \mathrm{~g}$ of $\mathrm{FeCl}_{3}$ without or with different concentrations of extracts was taken. They were incubated for $30 \mathrm{~min}$ at room temperature. At the end of incubation time $1 \mathrm{ml}$ potassium thiocyanate was added. Absorbance was measured at $450 \mathrm{~nm}$ in final $3 \mathrm{ml}$ solution. For both the forms of iron EDTA- $\mathrm{Na}_{2}$ was used as the standard.

\section{$/ 2 / \%\left(\mathrm{Fe}^{2+} / \mathrm{Fe}^{3+}\right)$ chelation $=(\mathrm{Ac}-\mathrm{As}) / \mathrm{Ac}^{*} 100$}

Where, Ac is the absorbance of the control and as is the absorbance of the sample.

\section{Results and Discussion}

\section{Percent yield}

Water extracts showed higher percent yield than methanol extracts (Table 1).

Table 1: Percent yield of various bean extracts.

\begin{tabular}{|c|c|c|}
\hline Types Of Beans & $\begin{array}{c}\text { \% Yield of Water } \\
\text { Extracts }\end{array}$ & $\begin{array}{c}\text { \% Yield Of } \\
\text { Methanol Extract }\end{array}$ \\
\hline Glycine max & 19.8 & 7.3 \\
\hline Vigna radiata & 5.6 & 4.4 \\
\hline Vigna aconitifolia & 11.9 & 5.5 \\
\hline
\end{tabular}

\section{DPPH scavenging assay}

The antioxidants react with the stable free radical DPPH (deep violet color) and convert it to 1,1-diphenyl-2-picryl hydrazine resulting in decoloration. The scavenging effect of extracts was expressed as (\%AA) percentage activity given in Table 2 \& 3. Vigna aconitifolia showed highest scavenging activity in water extracts followed by Vigna radiata which 
indicates that they contain more water soluble phenolic content than methanol. Data infers approx $90 \%$ antioxidant activity for moth and mung in water extracts. There was no significant effect of methanol on DDPH radical scavenging of beans.

Table 2: \% Antioxidant activity in methanol extracts.

\begin{tabular}{|c|c|c|c|}
\hline $\begin{array}{c}\text { Sample } \\
\text { Concentration }\end{array}$ & \multicolumn{3}{|c|}{ Methanol Extracts } \\
\hline & SOY & MUNG & MOTH \\
\hline $0.25 \mathrm{mg} / \mathrm{ml}$ & $22.34 \pm .03$ & $20.12 \pm .01$ & $13.19 \pm .02$ \\
\hline $0.5 \mathrm{mg} / \mathrm{ml}$ & $26.28 \pm .02$ & $48.94 \pm .02$ & $17.45 \pm .01$ \\
\hline $1.25 \mathrm{mg} / \mathrm{ml}$ & $51.07 \pm .01$ & $59.50 \pm .01$ & $25.96 \pm .01$ \\
\hline $2.5 \mathrm{mg} / \mathrm{ml}$ & $78.73 \pm .01$ & $68.08 \pm .02$ & $37.24 \pm .03$ \\
\hline
\end{tabular}

Table 3: \% Antioxidant activity in water extracts.

\begin{tabular}{|c|c|c|c|}
\hline $\begin{array}{c}\text { Sample } \\
\text { Concentration }\end{array}$ & \multicolumn{3}{|c|}{ Water Extracts } \\
\hline & SOY & MUNG & MOTH \\
\hline $0.25 \mathrm{mg} / \mathrm{ml}$ & $11.70 \pm .01$ & $26.60 \pm .02$ & $20.22 \pm .01$ \\
\hline $0.5 \mathrm{mg} / \mathrm{ml}$ & $26.60 \pm .05$ & $46.81 \pm .04$ & $32.98 \pm .01$ \\
\hline $1.25 \mathrm{mg} / \mathrm{ml}$ & $48.94 \pm .04$ & $84.05 \pm .06$ & $67.03 \pm .02$ \\
\hline $2.5 \mathrm{mg} / \mathrm{ml}$ & $74.47 \pm .06$ & $87.24 \pm .04$ & $89.36 \pm .02$ \\
\hline
\end{tabular}

Antioxidant Potential for Water and Methanol Extracts

\section{Total phenolic content}

Phenolic compounds are a class of antioxidant compounds which act as free radical terminators [10]. The water and methanol extracts of four varieties of beans were studied for their contents of total phenols. Table 3 shows the total phenolic content of extracts measured by Folin-Ciocalteau reagent in terms of gallic acid equivalent (GAE). The highest phenolic content was observed in Vigna aconitifolia and same pattern was found for the methanol extracts. The water extracts showed higher phenolic content which indicates water soluble phenols are dominant over methanol extracts (Figure 1).

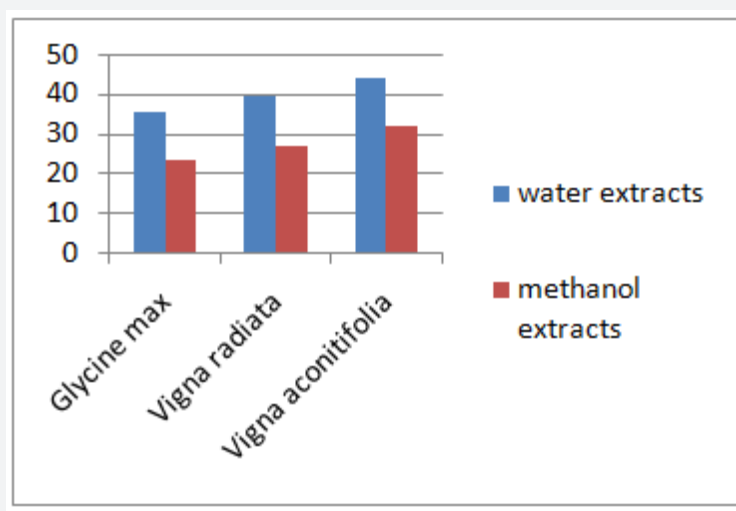

Figure 1: Total Phenol Content ( $\mu \mathrm{g}$ GAE/mg extract).

\section{Total flavonoid content}

The mechanisms of action of flavonoids are through scavenging or chelating process [11]. The flavonoid content of extracts was calculated as quercetin equivalent (QE) using alluminium chloride method as shown in Table 3. Vigna aconitifolia and Vigna radiata both contained highest flavonoid content for water extracts while the lowest was found in Glycine max in both conditions (Figure 2).

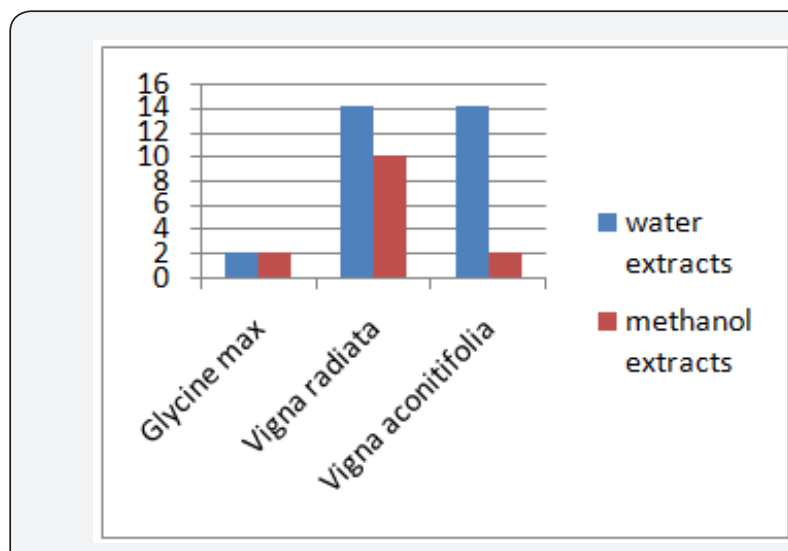

Figure 2: Total Flavanoid Content ( $\mu \mathrm{g} \mathrm{QE} / \mathrm{mg}$ extract).

\section{Metal chelation activity}

The main strategy to avoid free radical (ROS) generation that is associated with redox active metal catalysis involves chelating of the metal ions. $\mathrm{Fe}^{3+}$ with thiocyanate and $\mathrm{Fe}^{2+}$ with bipyridal forms complex giving red and pink colour respectively. In the presence of chelating agents, the complex formation is disrupted such that the colour of the complex is decreased. Measurement of reduction in color given by the decrease in absorbance therefore, allows the estimation of the chelating activity of the coexisting chelator. Both water and methanol extracts showed chelation towards the two forms of iron. Figure $3 \& 4$ shows that affinity of all the extracts towards $\mathrm{Fe}^{3+}$ was higher.

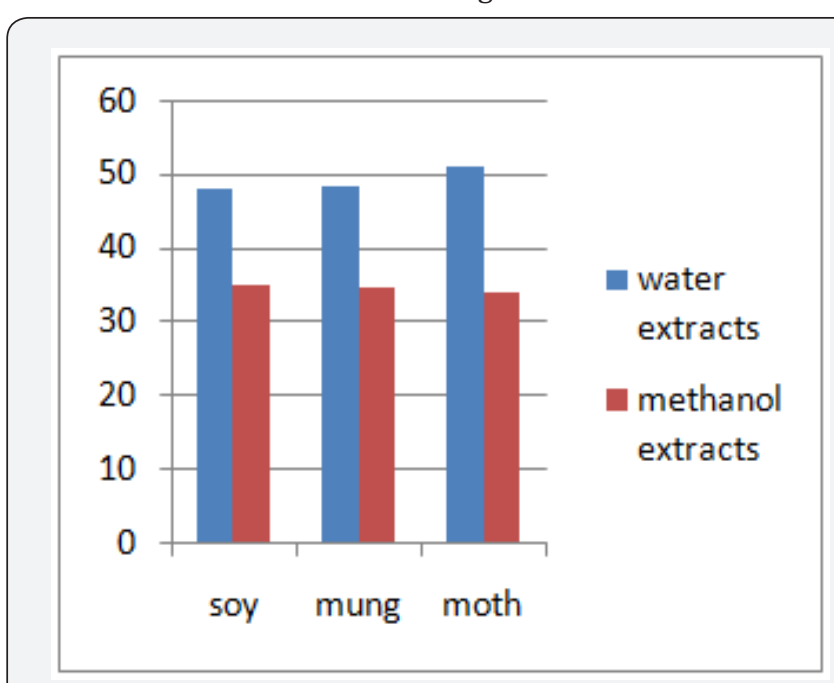

Figure 3: Iron (II) percent chelation activity. 


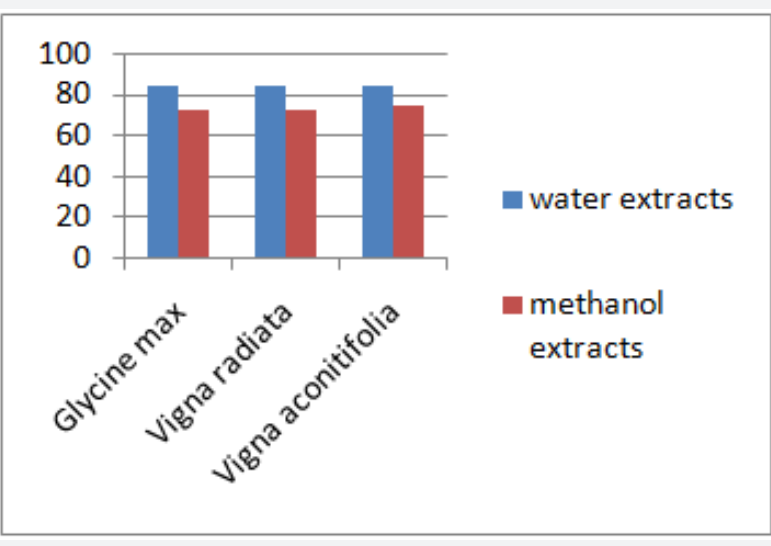

Figure 4: Iron (III) percent chelation activity.

\section{Conclusion}

These beans can be considered as good sources of antioxidants as shown by their flavanoid and phenol contents. Vigna aconitifolia found to be most potent antioxidant with highest phenolic content and antioxidant activity. A significant correlation was observed between antioxidant activity and phenolic content indicating that phenolic compounds contribute significantly to antioxidant activity of the investigated beans in water extracts due to presence of more water soluble phenols than methanol soluble phenols. Hence these beans may be utilized as functional food for the control of oxidative stress borne diseases in the form of nutraceuticals but further in vitro and in vivo studies are required to claim the same.

\section{References}

1. Lown JW (1993) Discovery and development of anthracycline antitumor antibiotic. Royal Society of Chemistry 22(3): 165-176.

2. Anwannil HG, Atta R (2006) Trends in ethnopharmacology. J Ethnopharmacol 100(1-2): 43-49.

3. Dahanuka SA, Kulkarni RA, Rege NN (2000) Pharmacology of medicinal plants and natural products. Indian Journal of Pharmacology 32: S81-S118.

4. Wang H, Liu T, Chen Y, Shiuan D (2007) Protective effect of freeze dried extract of vegetables and fruits on the hydroxyl radical mediated oxidative damage of DNA and decrease of erythrocytes deformability. Appl Biochem Biotechnol 141(2-3): 241-249.

5. Okeke IN, Lamikanra A, Edelma R (1999) Socioeconomic and behavioural factors leading to acquired bacterial resistance to antibiotics in developing countries. Emerg Infect Dis 5(1): 18-27.

6. Mondal SK, Chakraborty G, Gupta M, Mazumder UK (2006) In vitro antioxidant activity of Diospyros malabarica Kostel bark. Indian J Exp Biol 44(1): 39-44.

7. Mensor LL, Menezes FS, Leitao GG, Reis AS, Santos TC, et al. (2001) Screening of Brazilian plant extracts for antioxidant activity by the use of DPPH free radical method. Phytother Res 15(2): 127-130.

8. Ebrahimzadeh MA, Hosseinimehr SJ, Hamidinia A, Jafari M (2008) Antioxidant and free radical scavenging activity of Feijoasallowiana fruits peel and leaves. Pharmacologyonline 1:7-14.

9. Tripathi YB, Chaurasia S (2000) Interaction of S. nux-vomica products and iron: with reference to lipid peroxidation. Phytomedicine $7(6)$ : 523-528.

10. Shahidi F, Wanasundara PKJPD (1992) Phenolic antioxidants Critical Reviews. Crit Rev Food Sci Nutr 32(1): 67-103.

11. Cook NC, Samman S (1996) Flavonoids- chemistry, metabolism, cardioprotective effects, and dietary sources. Journal of Nutritional Biochemistry 7(2): 66-76.

\section{Your next submission with Juniper Publishers will reach you the below assets}

- Quality Editorial service

- Swift Peer Review

- Reprints availability

- E-prints Service

- Manuscript Podcast for convenient understanding

- Global attainment for your research

- Manuscript accessibility in different formats

( Pdf, E-pub, Full Text, Audio)

- Unceasing customer service

Track the below URL for one-step submission https://juniperpublishers.com/online-submission.php 